\title{
Life Cycle Analysis of Milkfish Fingerlings Production in Thailand
}

\author{
Prisna Pianjing and Jarunee Wites
}

\begin{abstract}
This study revealed the results from a life cycle inventory of milkfish (Chanos chanos) fingerlings production in Thailand and a life cycle assessment (LCA). A scope of study was a gate -to-gate of milkfish fingerlings production. Life cycle inventories were performed based on the production of $1,000,000$ fingerlings. The assessments of environmental impacts were global warming potential (GWP), acidification potential (AP), eutrophication potential (EP). There were 5 major stations of milkfish fingerlings production including the brood stock, breeding, nursery, live feed, and support station. The brood stock station exhibited the highest GWP at 51,128.38 $\mathrm{kg} \mathrm{CO}_{2}$ eq. The major source of GWP was from energy consumption. The highest AP was from breeding station at $12,794.75 \mathrm{~kg} \mathrm{SO}$ eq. The major source was from energy used for aeration and water pumping. The highest EP was from breeding station at $172,796.10 \mathrm{~kg} \mathrm{PO}_{4}$ eq. The use of feeds that contained lower fish meal and a good administration of feeding process could help to reduce the global warming potential. Application of alternative energy sources such as wind energy could decrease global warming and acidification impact.
\end{abstract}

Index Terms-Life cycle assessment, milkfish, fingerling production, Thailand.

\section{INTRODUCTION}

Milkfish (Chanos chanos) is one of the most important aquaculture species among the countries in Asia including, Indonesia, Philippine, and Taiwan [1]. The cultivation of milkfish can contribute in marine, estuarine, or fresh water aquatic systems due to the fact it is the euryhaline fish that can survive in broad range of salinity of aquatic system [2]. This provides the consistently increase in cultivations of milkfish. The world production for milkfish has expanded from 808.6 million tons in 2010 to 1041.4 million tons in 2018 [3]. Culture of milkfish needs fingerlings that are supplied from farms and catching the fries along the coastal area [2]. However, the wild-caught milkfish fries have consistently decreased due to the decrease of natural brood stocks [2]. Thus, productions of milkfish fries from farms have increased in order to supply adequate fries for milkfish farming. The harvested milkfish are mostly marketed fresh, chill, deboned, smoked, and frozen. Philippine is the major country that produces milkfish processing [2].

Manuscript received February 13, 2021; revised May 31, 2021. This work was supported in part by the grant from National Research Committee Office of Thailand (NRCT).

P. Pianjing is with the College of Allied Health Science, Suan Sunandha Rajabhat University, Bangkok, Thailand (e-mail: prisna.pi@ssru.ac.th).

J. Wites is with the School of Culinary Art, Suan Dusit University, Thailand (e-mail: charunee30@gmail.com)
In Thailand, the data inventories about milkfish culture are scarce. Thailand can produce the milkfish fry and fingerling since 2002 by induction of eggs production in breeding cement tank. The Prachuap Khiri Khan Coastal Fisheries Research and Development Center which is a part of Thai Department of Fisheries is the organization that produces the milkfish fry and supply the fingerlings [4]. The cultures of milkfish in Thailand appear in the provinces that locate along the coastal area. The Thai Department of Fisheries has used the marketing promotion to encourage consumption of milkfish by announcing that milkfish was the symbol fish of Prachuap Khiri Khan province [4]. This could help to promote tourism and encourage tourists to try food prepared from milkfish [4]. The milkfish processing such as deboned milkfish and fillet are produced by trained people in Prachuap Khiri Khan [4]. As for the initiative of the Thai Department of Fisheries that the government attempts to increase milkfish consumption, the need for milkfish fry and fingerlings will increase as a consequence. Therefore, the sustainable production the fingerlings should be encouraged in order to prevent the environmental degradation from the increase of fingerlings production.

Previous studies of environmental issues associated with milkfish aquaculture in Philippine showed the significant impacts relating to the high energy consumption and nutrients releasing from the farms [5], [6]. However, from study of [5], the fries and fingerlings milkfish that were used further for obtaining the adult milkfish were caught from natural and the extensive fingerling production from man-made was not included. This reflects the need of man-made fingerlings production in order to decrease the capturing milkfish fries from natural sources and can be the alternative process that leads to the sustainable aquaculture. Therefore, studying the environmental impact from milkfish fingerling production could be the useful data for improvement of the missing gap of knowledge of milkfish aquaculture.

However, there is no official data of milkfish production in Thailand and there is no available data about life cycle inventory of milkfish fingerlings production. The LCA is an important tool for evaluating environmental impact and helping to identify the hot spot of environmental impacts from the system. It is necessary to apply LCA to be a tool for sustainable milkfish fingerlings production and represent the data of milkfish inventory for further studies. This study was aimed to evaluate the environmental impacts from the production of milkfish fingerlings. The outcomes of this study can help to improve the fingerlings production system and reveal the point sources of significant environmental impact. 


\section{Methodology}

Life cycle assessment (LCA) is the common tool that can help to contribute to creating the sustainable aquaculture system [7]. The 4 frameworks of LCA include goal and scope of the LCA, life cycle inventory (LCI) analysis, life cycle impact assessment (LCAI) and interpretation [8].

\section{A. Goal}

The goal of this study was to evaluate the information of natural resources using, energy consumption and environmental burden derived from the milkfish fingerlings production unit by using LCA method. The outcome of this study could help to provide the information of natural resources consumption and the data base from this unit could help for setting the guidelines for decreasing the environmental burden derived from milkfish fingerlings production system. However, this study is a gate-to-gate approach which focuses on the inputs, outputs and environmental issue of the milkfish fingerlings production system. The impact categories of adult milkfish culturing and milkfish processing products were not included. The lacking of feed composition data was the limitation of this study which were considered to use reference data that was contributed in Thailand.

\section{B. Scope and System Boundary}

The study area is a Thai government work agency which is called Prachuap Khiri Khan Coastal Fisheries Research and Development Center. This research center is a part of the Thai Department of Fisheries as shown in Fig. 1. This center is the only one center that produces the fingerlings of milkfish in Thailand. This study focused on the fingerlings production system in the center and the scope of this study is shown in Fig. 2. The milkfish fingerlings production system comprises 5 major stations including, the brood stock station, live feed station, breeding station, nursery station, and support station. The nursery station comprises post larvae rearing unit and fry rearing unit. In this study, emissions from administration office and the using of electricity for lighting within the whole farm were excluded. The transportation of fish feed was excluded due to the lack of reliable data of the location of feed suppliers and the transportation method such as types of vehicles and distance from the suppliers to the center.

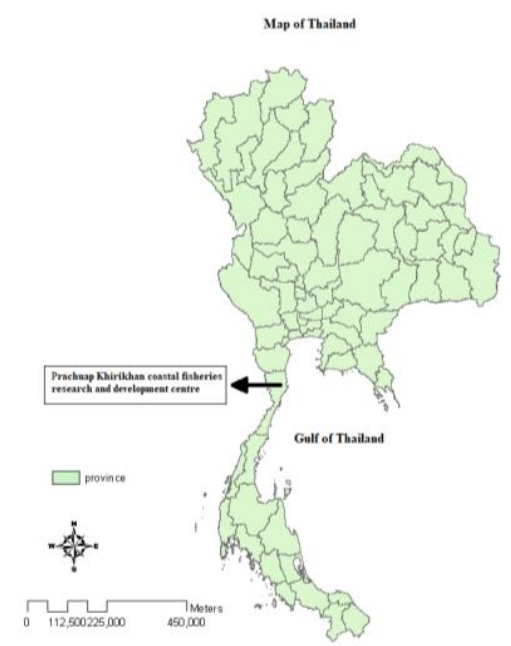

Fig. 1. The area of LCA of milkfish fingerlings production.

\section{Functional Unit}

In general, the functional unit of aquacultures should be set as weight of product such as 1 ton of fish or $1 \mathrm{~kg}$ of fish [9]. However, for the fingerlings production, the functional unit setting could not be set as weight of fingerlings. Due to the fact that the fingerlings will be sold as live fish from hatchery unit and the farmers will buy the fingerlings as number of live fingerlings and they will rear them in ponds or net cages as the amount of live fish/area. The hatchery units of several fish species export their products as live fish larvae per year. For example, the seabream and seabass hatchery units in Greece reported their annual production of seabream around 8.0 million larvae and 25.5 million larvae of seabass [10]. Therefore, the functional unit of this study was the production of milkfish fingerlings process for 1 cycle which took 1 year to finish the process and produced around $1,000,000$ fingerlings. Although the time period of fish larvae production takes for $4-7$ months, the maintenance of adequate brood stock should take place in order to supply the new batch of eggs and new breeders [10]. Therefore, the cycle of milkfish fingerling production should include the maintenance process of brood stocks which takes for 1 year-round of fingerlings production. This study did not focus on the FCR due to the fact that the milkfish fingerlings were very fragile. It is not practical to weight the fingerlings that were produced for selling as live fish for studying the FCR which may cause the fish die or deteriorate the fish body. Nevertheless, the appropriate way of FCR study may apply by setting the unit that specific for studying the FCR of fingerlings.

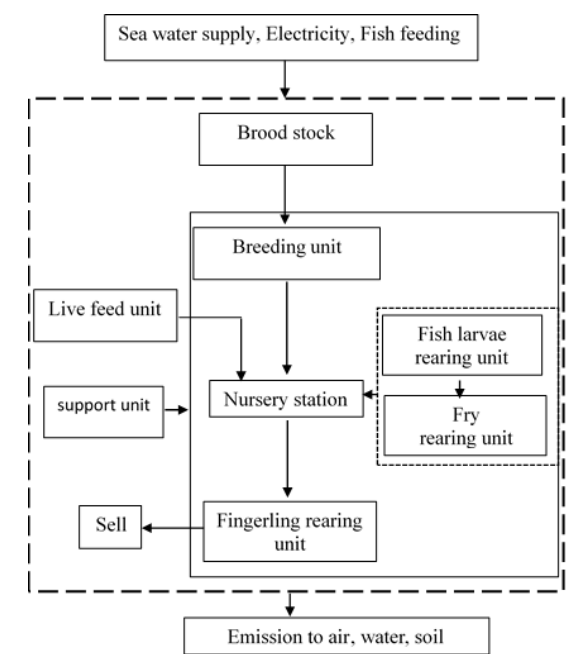

Fig. 2. System boundary of milkfish fingerlings production.

\section{Life Cycle Inventory Analysis (LCI)}

In this study, a gate-to-gate inventory data were derived from several sources and conducted based on ISO 14040 [11]. The primary data of sea water supply, type of fish feeding, the amount of feeding, time spending for aeration, and water pumping obtained from interviewing the officers on the site during 2018 - 2019. The water parameters were collected from effluent in each unit 3 times in wet and dry seasons during 2018-2019. The data of nitrate, ammonia, and phosphate concentrations were analyzed at the laboratory of the Environmental Center of Suan Dusit University in Bangkok, Thailand. 
The percentage of fish feed nutrition including protein, lipid, fiber and moisture were collected from labels on the packaging of fish feed. The fish feed used in the center showed only types of ingredients and percentage of nutritive values contained in the fish feed as shown in Table I. There were several brands of commercial feeds using in this center due to the fact that there is no specific fish feed for milkfish in Thailand. Farmers usually use the commercial herbivorous fish feed or catfish feed to rear the milkfish. Therefore, the amounts of raw materials of fish feed were calculated based on [12] which reported the data of shrimp feed that were produced in Thailand. The nutritive values of fish feed in this study comprise protein $35 \%$, lipid $4 \%$, fiber $4 \%$ and moisture $11 \%$ as shown in Table II. It was similar to commercial shrimp feed that was evaluated by the report of [12] as shown in Table II. Reference [12] revealed that shrimp feed of $1 \mathrm{~kg}$ contained protein $35 \%$, lipid $6 \%$, and fiber $2.5 \%$. Based on [12], the feed emitted methane $0.0015 \mathrm{~kg}$, carbon dioxide $1.29 \mathrm{~kg}$, nitrogen $0.0455 \mathrm{~kg}$, and phosphorus $0.00199 \mathrm{~kg}$. Therefore, this study will calculate the outputs parameters of fish feed at the same rate of [12].

The quantities outputs of total suspended solid, nitrate $\left(\mathrm{NO}_{3}\right)$, phosphate $\left(\mathrm{PO}_{4}\right)$ and ammonia $\left(\mathrm{NH}_{3}\right)$ were collected from effluent in each unit for 3 times which were related to the activities of each unit. The outputs of nutrients emissions were calculated based on the laboratory analysis results regarding the amounts of sea water discharged from each station. The concentrations of the parameters obtained from laboratory analysis were shown in Table III.

\section{E. Life Cycle Impact Assessment (LCIA)}

The CML Baseline 2002 was used for impact assessment method [13]. The impact categories were considered based on a study of [7], [14]. The selected impact categories in this study were global warming potential (GWP100; unit: $\mathrm{kg} \mathrm{CO}_{2}$ eq), acidification potential (AP; unit: $\mathrm{kg} \mathrm{SO}_{2}$ eq), and eutrophication potential (EP; unit: $\mathrm{kg} \mathrm{PO}_{4}$ eq). These categories have been reported to be the main environmental impacts of the aquaculture [7]. However, based on [14] the net primary production (NPP) assessment was excluded due to the lack of the fish weight and the specific value of carbon content in milkfish fingerlings.

TABLE I: FEED INGREDIENTS

\begin{tabular}{|l|l|}
\hline \multicolumn{1}{|c|}{ This study } & \multicolumn{1}{c|}{ Reference [12] } \\
\hline Fish meal & Fish meal $(34.19 \%)$ \\
\hline By product from poultry & Poultry meal $(2.78 \%)$ \\
\hline By product from sea food & Cuttle fish meal $(4.78 \%)$ \\
\hline Wheat flour & Baked shellfish $(0.34 \%)$ \\
\hline Soy bean & Shrimp shell meal $(2.10 \%)$ \\
\hline Fish oil & Soy bean $(17.12 \%)$ \\
\hline Maize & Wheat flour $(28.78 \%)$ \\
\hline Broken rice & Broken rice $(0.34 \%)$ \\
\hline Casava & Rice bran extract $(0.74 \%)$ \\
\hline Vitamin & Kelp meal $(0.74 \%)$ \\
\hline Mineral & Wheat gluten $(0.01 \%)$ \\
\hline Food preservative & Particle $(8.08 \%)$ \\
\hline & Water $(0.74 \%)$ \\
\hline
\end{tabular}

The emission factors (EF) of $\mathrm{CO}_{2}, \mathrm{SO}_{2}$ and $\mathrm{NO}_{\mathrm{x}}$ from electricity using were $589.25 \mathrm{~g} / \mathrm{kWh}, 0.43 \mathrm{~g} / \mathrm{kWh}$ and 1.28 $\mathrm{g} / \mathrm{kWh}$ respectively [15]. The global warming equivalent factors in term of $\mathrm{kg} \mathrm{CO}_{2}$ eq were considered based on [16] and the equivalent factors of $\mathrm{CO}_{2}$ and $\mathrm{NO}_{\mathrm{x}}$ were 1 and 310 respectively.

TABLE II: NUTRITIVE VALUES OF FEED

\begin{tabular}{|l|c|c|}
\hline $\begin{array}{l}\text { Nutritional } \\
\text { content }\end{array}$ & This study (\%) & Reference [12] (\%) \\
\hline protein & 35 & 35 \\
\hline Lipid & 4 & 6 \\
\hline Fiber & 4 & 2.5 \\
\hline Moisture & 11 & Not available \\
\hline Ash & Not available & 12 \\
\hline
\end{tabular}

TABLE III: PARAMETERS OF DRAINAGE SEA WATER OBTAINED FROM LABORATORY ANALYSIS

\begin{tabular}{|l|c|c|c|c|}
\hline \multirow{2}{*}{$\begin{array}{l}\text { Parameters } \\
(\mathrm{mg} / \mathrm{L} \pm \mathrm{SD})\end{array}$} & \multicolumn{4}{|c|}{ Station } \\
\cline { 2 - 5 } & Brood stock & Breeding & Nursery & $\begin{array}{l}\text { Live } \\
\text { feed }\end{array}$ \\
\hline $\begin{array}{l}\text { Suspended } \\
\text { solid }\end{array}$ & $126.56 \pm 3.15$ & $140.33 \pm 0.950$ & $149.00 \pm 6.575$ & - \\
\hline $\mathrm{NO}_{3}$ & $0.930 \pm 0.050$ & $0.025 \pm 0.005$ & $0.000 \pm 0.00$ & - \\
\hline $\mathrm{PO}_{4}$ & $0.001 \pm 0.000$ & $0.005 \pm 0.002$ & $0.005 \pm 0.001$ & - \\
\hline $\mathrm{NH}_{3}$ & $1.620 \pm 0.090$ & $1.870 \pm 0.146$ & $3.360 \pm 0.544$ & - \\
\hline
\end{tabular}

The amount of $\mathrm{CO}_{2}, \mathrm{~N}_{2} \mathrm{O}$, and $\mathrm{CH}_{4}$ emissions from liquefied petroleum gas (LPG) combustion were calculated following the IPCC 2006 guideline [16]. The emission factors of $\mathrm{CO}_{2}, \mathrm{~N}_{2} \mathrm{O}$, and $\mathrm{CH}_{4}$ of LPG were $56100 \mathrm{~kg} \mathrm{CO}_{2} / \mathrm{TJ}$ fuel, $0.1 \mathrm{~kg} \mathrm{~N}_{2} \mathrm{O} / \mathrm{TJ}$ fuel, $1 \mathrm{~kg} \mathrm{CH} / \mathrm{TJ}$ fuel respectively. The low heating value (LHV) of LPG was $47.3 \mathrm{TJ} / \mathrm{Gg}$ [14]. The global warming potential from LPG combustion was calculated according to equation (1) (2) and (3) as follows:

$\mathrm{CO}_{2}$ eq emission $=\mathrm{CO}_{2}$ emission $+\left(\mathrm{N}_{2} \mathrm{O}\right.$ emission $\left.\mathrm{x} 310\right)$ $+\left(\mathrm{CH}_{4}\right.$ emission $\left.\mathrm{x} 21\right)$

Gas emission $=\Sigma\left(\mathrm{AD}_{\text {fuel }} \mathrm{x}\right.$ gas emission factor $) / 1,000,000(2)$

The AD fuel refers to the amounts of fuel that are burned to be energy source (TJ/yr) and the AD fuel can be calculated as follow:

AD fuel = LPG used $(\mathrm{kg} / \mathrm{yr}) \times \mathrm{LHV}(\mathrm{TJ} / \mathrm{Gg})$

Note: $\mathrm{TJ}=$ Terajoule

The acidification equivalent factors in term of $\mathrm{kg} \mathrm{SO}_{2}$ eq were considered based on [14]. The equivalent factors of $\mathrm{SO}_{2}$, $\mathrm{NO}_{\mathrm{x}}$ were 1 , and 0.5 respectively [14].

The eutrophication equivalent factors in terms of $\mathrm{kg} \mathrm{PO}_{4}$ eq were considered based on [17] and the equivalent factors of $\mathrm{PO}_{4}, \mathrm{NO}_{3}, \mathrm{NH}_{3}$, nitrogen $(\mathrm{N})$ and phosphorus $(\mathrm{P})$ were 1 , $0.13,0.35,0.42$ and 3.06 respectively.

\section{RESUlTS AND DISCUSSION}

Production of milk fish fingerlings in the Prachuap Khiri Khan Coastal Fisheries Research and Development Center usually ends within a year. The breeding process and hatchery process took 5-6 months for production of fingerlings. However, rearing of brood stocks and some of unsold fingerlings remain continuously. Therefore, the inputs and outputs parameters of each unit relating to fingerlings production were determined based on 1 year duration.

The five stations for production of milkfish fingerlings in Thailand are as shown in Fig. 2. The data of selected water 
parameters analysis were shown in Table III. The activities in each unit, inputs, and outputs data are described below.

Brood stocks of adult milkfish were reared in ponds that were separated from the hatchery station. The milkfish that are older than 1 year were selected to be reared in this unit until they were 3-5 years old which prompt to be the breeders for production of new generation of milkfish. There were 3 ponds in this unit each of which approximately contained 200 adult milkfish, and 1 pond for storage the sea water. The average of each milkfish body weight was $2 \mathrm{~kg}$. The activities of this unit were pumping of sea water into the pond and using surface aerators for oxygen supply. The milkfish were fed twice daily with the feed that contain $35 \%$ of protein at the rate of $3 \%$ of body weight. The $80 \mathrm{~kg} /$ day of fish feed were used for the whole unit. The volumes of sea water in all ponds were 1,147,000 liters. The sea water in the ponds was discharged at $50 \%$ of the whole volume in each week. The inputs data of this unit are summarized in Table IV.

A live feed station supported the production of rotifer and green algae for the larvae of milkfish. The activities of this unit were boiling the water for culturing the plankton, pumping water into the unit and using aerators for supplying oxygen. The inoculation room in this unit was contributed in the air conditioning room. A 20,000 BTU air condition was installed in the inoculation room and used for 8 hours/day. The electricity and water in this unit were supplied by the supporting unit. The drainage of used water in this station was recycled for another unit. Therefore, there was no data of parameters derived from sea water drainage such as nitrate phosphate and ammonia. The $15 \mathrm{~kg}$ cylinder containing liquefied petroleum gas (LPG) was used for heating the water. The $30 \mathrm{~kg}$ of LPG/month were used for production and seeding of the plankton. In 1 day, the larvae of milkfish consumed $100 \mathrm{~g}$ of water containing rotifer and green algae and they consumed the plankton for $10-15$ days.

The hatchery activities comprised breeding station, larvae, and fry nursery units. The 300 mature milkfish that were 5 years old were taken to be reared in the cement tanks as the breeders. The average body weight of each brood stock was around $2 \mathrm{~kg}$. In 1 cycle of fingerlings production, the mature milkfish bred during March - June and spawned the eggs during mid night. The 3,200,000 eggs were produced and the survival rate after hatching out was $40 \%$. It took 28-30 hours for the eggs to hatch out. The 1,000,000 fingerlings were produced in 1 cycle of production. The mature milkfish were cultured for 8 years; after that the new mature milkfish would be taken to the breeding unit. This unit drained the sea water every day and the new sea water from supporting units was supplied. The mature milkfish were fed at the rate of $3 \%$ of body weight twice a day. In this unit the aerators were used to supply oxygen for the fish.

During the spawning period, the fish eggs were consistently collected and moved to nursery tanks for the hatchery process. The hatched eggs were reared in the cement tanks until they became the fries and fingerlings. The larvae were fed with rotifers and green algae for 10 days as already mentioned. After 10 days, the larvae became the fries and they were fed with fish feed that was specific for fish fries. The milkfish fries were fed 3-4 times/day at the rate of 100 $\mathrm{g} /$ day. It took 30 days of fries culturing to become the fingerlings with the size of $2-3 \mathrm{~cm}$ long that can be subjected to be cultured in ponds or sold to farmers. However, some of the residual fingerlings were cultured in the net cages in pond for 6 months and then they were moved out from net cages and cultured in brood stock ponds. Due to the fact that there was no precise data to report on how much the fingerlings were sold for each cycle, this study will assume that all of the fingerlings were sold out. It took 7 months to culture the larvae, fries and fingerlings until the last batch of eggs production. The farmers who came to buy the fingerlings at the research center took the milkfish fries to hatch in net cages in ponds. In Thailand, most of juvenile milkfish are cultured in combination with shrimp culture. The co-culture of milkfish and shrimp gives the advantage of water quality improvement in shrimp pond. However, until now, there is no available data of the number of farmers who culture milkfish with shrimp and there is no data of the milkfish production in Thailand.

Breeding, nursery and live feed stations received the water supply and aeration from the supporting units. The energy supply for water pumping machines and aerators came from the electricity from power plants that located outside the research center. There were 11 centrifugal water pumping machines which were used for several points to bring sea water into the process. The sea water used in the center came from natural ditch that brings sea water from Prachaup Khiri Khan Bay. Before supplying the sea water to breeding and nursery stations, the water treatment processes including precipitation and disinfection were contributed. The $20 \mathrm{~g}$ of oxytetracycline/ton of water was used as the disinfected chemical. However, we excluded the environmental impact of using this chemical due to the fact that it was too low in comparison with the other input parameters. The inventories data from the supporting unit were evaluated by aggregating the activities with other units.

The commercial catfish feed was the major feed used in this center. The feeds were bought from several suppliers and there was no precise time of ordering and there were no precise methods of transportation to the center. The empty feed bags were sold for recycling and they were moved out from the research center by several buyers. Therefore, this study excluded the transportation of feed and the amount of solid waste occurring from the using of feed.

The environmental impact of milkfish fingerlings production is shown in Table V. The brood stock and breeding stations exhibited the high level of environmental impact in comparison with nursery and live feed stations. According to the Table V and Fig. 3, the brood stock station exhibited highest global warming potential at $37.57 \%$. The highest impact of acidification was found to be at $37.95 \%$ from breeding unit. The highest eutrophication impact was found to be at $89.02 \%$ from breeding unit.

The nursery station and live feed station showed lower environmental impacts in all categories. The major activities in the brood stock station and breeding station were the using energy for aerators and water pumping. The major causes of GWP and AP in this study were from energy consumption. The marine fish hatchery unit is a very intensive system that needs high amount of energy demand in order to contribute to the optimum environmental condition such as oxygen supply 
and good water quality for the fish larvae [10]. The uses of aerators and water pumping machines were the causes of greenhouse gases emissions. In this study, energy consumption caused $57.44 \%$ for GWP and the highest energy consumption was from the breeding unit. This unit consumed high energy for water pumping and aerator. The high energy consumption can cause the high cost of fish production as well as environmental burden. The cleaner technology of energy supply for milkfish fingerlings such as wind and solar energy should be addressed in order to decrease the environmental impact.

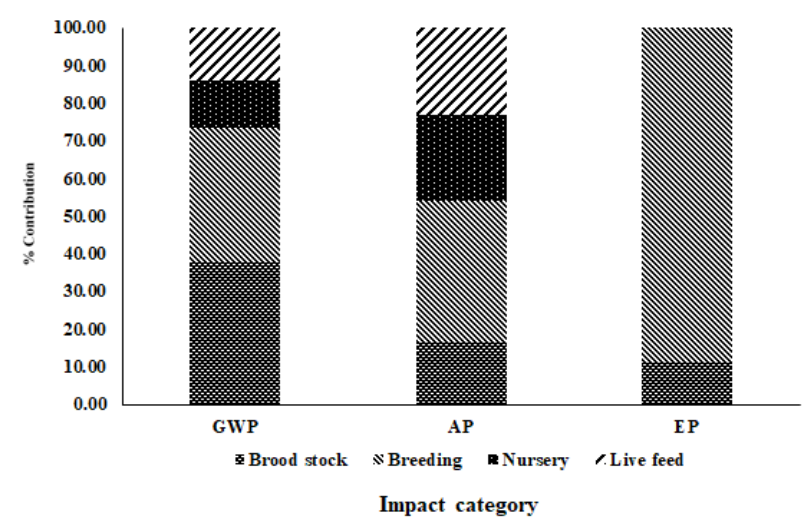

Fig. 3. Impact contributions from the process of production of 1 cycle of milkfish fingerlings.

TABLE IV: INPUTS AND OUTPUTS PARAMETERS INVENTORY AT MILKFISH FINGERLINGS PRODUCTION CENTER

\begin{tabular}{|c|c|c|c|c|}
\hline \multirow[t]{2}{*}{ parameters } & \multicolumn{4}{|c|}{ stations } \\
\hline & $\begin{array}{c}\text { Brood } \\
\text { stock }\end{array}$ & Breeding & Nursery & $\begin{array}{l}\text { Live } \\
\text { feed }\end{array}$ \\
\hline $\begin{array}{l}\text { Inputs } \\
\text { Sea water } \\
\text { storage/unit } \\
\text { (liter) }\end{array}$ & $1,147,000$ & $1,200,000$ & 20,000 & 10,000 \\
\hline $\begin{array}{l}\text { Adult milkfish } \\
\text { (Number of fish in } \\
\text { unit) }\end{array}$ & 600 & 300 & - & - \\
\hline Fish eggs & - & $3,400,000$ & - & - \\
\hline $\begin{array}{l}\text { Fingerlings } \\
\text { (Number of fish) }\end{array}$ & - & - & $\begin{array}{r}1,000,00 \\
0\end{array}$ & - \\
\hline Fish feed (kg/yr.) & 29,200 & 14600 & 21 & - \\
\hline Electricity (kWh) & 12,718 & 29,711 & $17,692.5$ & 18,177 \\
\hline LPG (kg/yr.) & - & - & - & 360 \\
\hline $\begin{array}{l}\text { Oxytetracyclin } \\
\text { (kg/yr.) }\end{array}$ & & & 21.9 & 1.095 \\
\hline $\begin{array}{l}\text { Outputs } \\
\text { Sea water drainage } \\
\text { (Million liter/yr.) }\end{array}$ & 29.822 & 146 & 5.84 & 0.12 \\
\hline $\begin{array}{l}\text { Suspended solid } \\
\text { (ton/yr.) }\end{array}$ & $3,774.27$ & 21,754 & 2.24 & - \\
\hline $\mathrm{NO}_{3}(\mathrm{~kg} / \mathrm{yr}$. $)$ & $27,913.39$ & 14.6 & 0.4 & - \\
\hline $\mathrm{PO}_{4}(\mathrm{~kg} / \mathrm{yr})$. & 29.82 & 730 & 0.08 & - \\
\hline $\mathrm{NH}_{3}(\mathrm{~kg} / \mathrm{yr})$. & $48,311.64$ & 490,560 & 29.92 & - \\
\hline
\end{tabular}

The effect from fish feed was found to be at $42.56 \%$ for GWP. The highest global warming impact from the feed was found in the brood stock station due to the using of highest amount of feed when compared to other stations. This finding is similar to the reports of [9] and [18] which indicated that fish feed was the main cause of environmental impact from Nile tilapia farming. Types of feed ingredients affect the environmental impact due to the different production processes and raw material sources [9]. Several studies have indicated that the main global warming impact from fish feed were contributed by major composition including fish meal and soy bean [9], [14], [18]. Several studies have suggested replacing the fish meal by using soy bean or protein from plants in order to decrease carbon emission [14], [18]-[20]. However, a study of [14] proposed that substitution of fish derived composition with plant ingredients does not improve significant global warming impact. Reference [14] suggested using by-products from fish meal instead of standard fish meal for more significant improvement of global warming impact. However, using of fish by-products can lead to increase eutrophication impact due to high content of dietary phosphorus in fish by-products [14]. Therefore, it is important to remind that replacing of some ingredients in fish feed may not give advantage in all impact categories. Hence, substitution of major ingredient by new materials should consider all aspects of environmental impact.

The eutrophication impact found in this study were contributed by the $\mathrm{NO}_{3}, \mathrm{PO}_{4}$ and $\mathrm{NH}_{3}$ discharged from each unit. These nutrients are the most common water parameters of aquafarm that are monitored in all regions [21]. The breeding station exhibited the highest eutrophication impact which was related to the highest amount of releasing the sea water. $\mathrm{NH}_{3}$ discharged from the breeding station was the main cause of eutrophication impact. The fish feed is the main import nutrients to the farming system and exhibited significant impact to eutrophication effect [21]. With regard to studies of [9] and [18], it might be assumed that the eutrophication impact in this study was mainly contributed by fish feed. However, using of nutrients concentrations from water analysis as the parameters for eutrophication determination may lead to the unreliable result due to the fact that the parameters from water analysis exhibit the high variation in sampling technics and analysis methods which require validation and regular water sampling from the study site [21]. Using of nutrient-balance based model as proposed by [21] may give the alternative result of nutrients emission. The proposed model suggested using a calculation method which was related to the contents of $\mathrm{P}, \mathrm{N}$, digested nutrient in feed and using the ambient $\mathrm{NH}_{3}$ as well as river flow characteristic to determine nutrient emission. However, this study did not use the nutrient-balance method due to the fact that the result of data inventory cannot take the reliable feed compositions, feed consumed rate, FCR and the flow of water in the ditch. However, further studies on the nutrient balance base should be addressed for the eutrophication determination in order to contribute the alternative method for impact assessment.

The using of high volume of sea water in each unit reflected the high demand of good quality of sea water and the high level of water pollution emission. Hence, recycling 
of sea water could help to reduce the release of waste and surplus nutrients from the milkfish fingerlings production.

TABLE V: ENVIRONMENTAL IMPACTS OF 1 CYCLE OF MILKFISH FINGERLINGS PRODUCTION

\begin{tabular}{|c|c|c|c|}
\hline \multirow[t]{2}{*}{ station } & \multicolumn{3}{|c|}{ Impact category } \\
\hline & $\begin{array}{c}\text { Global } \\
\text { warming } \\
\text { potential } \\
\left(\mathrm{kgCO}_{2} \mathrm{eq}\right)\end{array}$ & $\begin{array}{l}\text { Acidification } \\
\text { potential } \\
\left(\mathrm{kg} \mathrm{SO}_{2} \mathrm{eq}\right)\end{array}$ & $\begin{array}{c}\text { Eutrophication } \\
\text { potential } \\
\quad\left(\mathrm{kgPO}_{4} \mathrm{eq}\right)\end{array}$ \\
\hline Brood stock & $\begin{array}{r}51,128.38 \\
(37.57 \%)\end{array}$ & $\begin{array}{l}5,476.88 \\
(16.24 \%)\end{array}$ & $\begin{array}{r}21,304.04 \\
(10.98 \%)\end{array}$ \\
\hline Breeding & $\begin{array}{r}48,590.43 \\
(35.71 \%)\end{array}$ & $\begin{array}{r}12,794.75 \\
(37.95 \%)\end{array}$ & $\begin{array}{r}172,796.10 \\
(89.02 \%)\end{array}$ \\
\hline Nursery & $\begin{array}{r}17,473.44 \\
(12.84 \%)\end{array}$ & $\begin{array}{l}7,619.09 \\
(22.60 \%)\end{array}$ & $\begin{array}{r}11.13 \\
(6.62 \%)\end{array}$ \\
\hline Live feed & $\begin{array}{r}18,879.59 \\
(13.87 \%)\end{array}$ & $\begin{array}{l}7,827.74 \\
(23.22 \%)\end{array}$ & $\begin{array}{r}0.00 \\
(0 \%)\end{array}$ \\
\hline
\end{tabular}

\section{CONCLUSION}

The life cycle inventories and life cycle analysis in this study indicated the hotspot of environmental impact from the milkfish fingerlings production and the gap of knowledge about life cycle inventory of milkfish hatchery unit. The results from this study showed that the GWP and AP were contributed by extensive energy consumption for water pumping and aerators. The EP was associated with nutrients input from fish feed and discharged via effluent from each unit. Using of alternative energy sources and recycle of sea water are the significant methods to reduce environmental impacts from milkfish fingerlings production. The FCR of milkfish fingerlings and the composition of feed in this study should be studied further in order to have the reliable data for further assessment.

\section{CONFLICT OF INTEREST}

The authors declare no conflict of interest.

\section{AUTHOR CONTRIBUTIONS}

Pianjing P. supervised the analysis and wrote the paper, Wites J. contributed data collection and; all authors had approved the final version.

\section{ACKNOWLEDGMENT}

The authors acknowledge the funding support from the National Research Committee Office, Thailand (NRCT). We appreciate the kindness of the Director of Prachuap Khiri Khan Coastal Fisheries Research and Development Center for providing the accommodation and we appreciate the kindness of all the officers in the research center for their advices and helping to collect the data.

\section{REFERENCES}

[1] J. W. Fitzgerald, Milkfish Aquaculture in the Pacific Potential for the Tuna Loneline Fishery Bait Market, Secretariat of the Pacific community aquaculture section Noumea, New Caledonia, p. 6, April 2004.

[2] Food and Agriculture Organization of the United nation, Chanos chanos (Forsskal, 1775), Culture Aquatic Species Information Programme, pp. 2-4. 2006.

[3] Food and Agriculture Organization of the United nation, The State of World Fisheries and Aquaculture 2020. Sustainability in Action, Rome p. 30, 2020.

[4] P. Kosawatpat, "Milkfish: Now choice for aquaculture in Thailand," International Workshop on Resource Enhancement and Sustainable Aquaculture Practice in Southeast Asia (RESA). Tigbaun, Philippines: Aquaculture Department, Southeast Asia, Asian Fisheries Development Center, p. 99, 2014.

[5] M. Holmer, N. Marba, J. Terrados, C. M. Duarte, and M. D. Fortes, "Impact of milkfish (Chanos chanos) aquaculture on carbon and nutrient fluxes in the Bolinao area, Philippine," Mar Pollut Bull, vol. 44, pp. 685-696, July 2002.

[6] J. Aubin, A. baruthio, R. Munkung, and J. lazard, "Environmental performance of brackish water polyculture system from a life cycle perpective: A Filipino case study," Aquac, vol. 435, pp. 217-227, October 2015.

[7] F.A. Bohnes and A. Laurent. "LCA of aquaculture system: methodological issue and potential improvements," Int L Life Cycle Asess, vol. 24, pp. 324-337, August 2018

[8] K-M. Lee and A. Inaba, Life Cycle Assessment Best Practice of ISO 14040 Series, Ministry of commerce industry and energy Republic of Korea. pp 1-30, February 2004.

[9] D. Hayman, M. A. Malek, and M. M. Hanafiah, "Life cycle assessment of Nile tilapia (Oreochromis niloticus) farming in Kenyir lake, Terengganu," Sustainability, vol. 12, pp. 1-13, December 2020.

[10] C. Ioakeimidis, H. Polatidis, and D. Haralambopoulos, "Use of renewable energy in aquaculture: An energy audit case-study snalysis," Glob, vol. 15, pp. 282-294, September 2013.

[11] ISO 14040:2006, "Environmental management-life cycle assessment-principle and framework, International organization for standardization," Geneva, Switzerland, 2006, pp. 1-20.

[12] W. Suksathit, "Comparative life cycle assessment of Pacific white shrimp (Litopenaeus vannamei) feed using fish meal or soy meal as the main ingredient," Masterdegree dissertation, Graduate School, Kasetsart Univ. Bangkok, Thailand, 2008.

[13] J. B. Guinee, Handbook on Life Cycle Assessment. OPERATIONAL Guide to the ISO Standard, Kulwar Academic Publishers, DORDRECHT, 2002, pp. 52-88.

[14] E. Papatryphon, J. Petit, A. J. Kaushik, and H. M. G. Warf, "Environmental impact assessment of salmonid feeds using life cycle assessment (LCA)," Ambio, vol. 33, pp. 316-323, August 2004

[15] P. Krittayakasem. S. Patumsawad, and S. Garivait, "Emission inventory of electricity generation in Thailand," JSEE, vol.2, pp. 65-69, 2011.

[16] IPCC, "Energy," 2006 IPCC Guideline for National Greenhouse Gas Inventories, Japan: IGES 2006, vol. 2, pp. 2-22. 2006.

[17] R. Heijungs, J. B. Guinee, G. Huppes, R. M. Landneijer, H. A. Haes, and A. W. Sleewijk, Environmental Life Cycle Aseesment of Product. Back Ground - Ooctober 1992, Centre of Environmental Science, Leiden, Netherland, pp. 101-102, 1992.

[18] P. Pongpat and R. Tongpool, "Life cycle assessment of fish culture in Thailand : Case study of Nile tilapia and striped catfish," IJESD, vol. 4 pp. 608-612, October 2013.

[19] R. Mungkung, J. Aubin, T. H. Prihadi, J. Slembrouck, and H. M. G. Warf, "Life cycle assessment for environmentally sustainable aquaculture management: A case study of combined aquaculture systems for carp and tilapia," J. Clean. Prod, vol. 57, pp. 249-256, June 2013.

[20] Food and Agriculture Organization of the United nation, Greenhouse Gas Emissions from Aquaculture. A Life Cycle Assessment of Three Asian System, Rome, pp. xi-xiii, 2017.

[21] E. Papatryphon, J. Petit, and H. M. G. Warf, "Nutrient-balance modeling as a tool for environmental management in aquaculture: The case of trout farming in France," Environ Manage, vol. 35, pp. 161-174, February 2005.

Copyright (C) 2021 by the authors. This is an open access article distributed under the Creative Commons Attribution License which permits unrestricted use, distribution, and reproduction in any medium, provided the original work is properly cited (CC BY 4.0). 


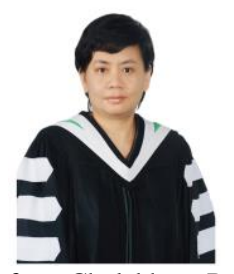

Prisna Pianjing was born in Thailand. She is an assist. prof. of public health program, College of Allied Health of Suan Sunandha Rajabhat University. She graduated with her master degree in environmental science from Kasetsart University and graduated with her $\mathrm{Ph} . \mathrm{D}$ in environmental engineering and management from Asian Institute of Technology, Thailand . Dr. Pianjing received the ADB scholarship from Chulabhorn Research Institute for studying for her Ph.D.

She started her career after graduating with $\mathrm{Ph} . \mathrm{D}$ at the environmental science program in Suan Dusit University in 2012. She moved to Suan Sunandha Ratjabhat University in 2017. She is interested in environmental issues such as LCA, ecology, environmental toxicology, health risk assessment, food and nutrition. She has received the research grants from NRCT every year since 2012 to 2020.

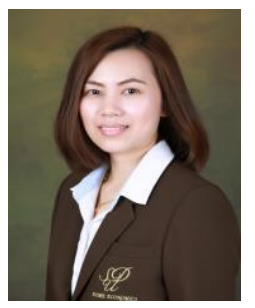

Jarunee Wites was born in Thailand. She is an instructor of home economics program, School of Culinary Art, Suan Dusit University. She graduated with her Master degree in home economics from Kasetsart University, Thailand.

She started to work as an instructor in 2012 at School of Culinary Art, Suan Dusit University. She focuses on research about contribution of new menus from fish and investigates the nutritive value. She also is interested in milkfish processing and she has expertise in deboned milkfish. Her latest article is "Development of Thai Food Recipes from Milkfish (Chanos chanos (Forskal, 1775))" published in Journal of Home Economic, Volume 62, Number 3, September - December 2019. She received the research grants from NRCT about Development of Thai Desserts from Nile tilapia, Development Thai Food from Milkfish, and Development of Soft Drinks Using Stevioside to Substitute for Sugar in 2012, 2017 and 2018 respectively. 